\title{
AIKUISKOULUTUKSEN KYSYNTÄ JA TYÖVOIMAN TARVE
}

Turkulaiset tutkijat Osmo Kivinen, Risto Rinne, Sakari Ahola ja Arto Kankaanpää julkaisivat vuoden vaihteessa kirjan "'Työelämä, koulutus ja ennusteet" (Opetusministeriön suunnittelusihteeristön julkaisuja 6/1989, Valtion painatuskeskus, Helsinki). Teoksen yksi luku on omistettu koulutussuunnittelun neuvottelukunnan laatiman "'Väestön koulutus 2000" -mietinnön (Helsinki 1988) kritiikille. Kommentoin tässä turkulaisten niitä näkemyksiä, jotka liittyvät aikuiskoulutuksen määrälliseen suunnitteluun.

\section{Käännepiste}

Aikuiskoulutuksen kehittämisestä on puhuttu ponnekkaasti toistakymmentä vuotta. Siihen verrattuna aikuiskoulutuksen todellinen eteneminen on ollut vähäistä. Vasta viime vuosina asiaan on tartuttu kunnolla.

"'Väestön koulutus 2000" -mietinnössä asetetaan ensimmäistä kertaa kokonaisvaltaiset aikuiskoulutuksen määrälliset pitkän aikavälin tavoitteet. Mietintö on selvä käännepiste, voisi jopa sanoa historiallinen askel koulutuksen kehittämisessä. Tavoitteet vaikuttavat ja ovat jo vaikuttaneet vahvasti kaikkeen siihen, mitä aikuiskoulutuksen kentässä tapahtuu.

Tähän asiaan tutkijat eivät kuitenkaan kiinnitä mitään huomiota, vaan keskittyvät etsimään esityksien todellisia ja kuviteltuja heikkouksia. 


\section{Työvoiman tarve vai koulutushalukkuus?}

Neuvottelukunta on pyrkinyt tavoiteluvuissaan tyydyttämään sekä väestön koulutustarpeita että työelämän tarpeita. Tarpeet voivat olla ristiriitaisia, mihin tutkijat kiinnittävät huomionsa. "Väestön koulutushalukkuus ei täsmää työelämän tarpeisiin. Tarkemmin perustelematta neuvottelukunta väittää, että sen esittämät jatko-opintomahdollisuuksien ja aikuiskoulutuksen laajennukset lieventäisivät kyseistä ristiriitaa. Näinköhän metallialan lattiatason tehtävien työvoimapula eliminoituisi aikuisille tarkoitettujen ammattikoulupaikkojen avulla?"' (s. 88)

Neuvottelukunnan esitysten tavoitteena ei ole poistaa koulutushalukkuuden ja työvoimatarpeiden välistä ristiriitaa, vaan kehittää aikuiskoulutusta siitä huolimatta. Varsinaiset ristiriidat, joita pyritään ratkaisemaan, on koulutustarjonnan niukkuuden ja väestön koulutuksen sekä toisaalta ammatitaitoisen työvoiman tarjonnan ja sen kysynnän välillä. Jos lisäämme koulutuspaikkoja, ratkaisemme ensimmäistä ristiriitaa. Jos kohdennamme sen niille aloille, joilla on tai arvioidaan tulevaisuudessa olevan työvoiman tarvetta, ratkaisemme toista ristiriitaa. Jos teemme sekä että, saamme vastauksen molempiin ongelmiin.

Metallialalle ei ilmeisestikään ole kovin paljon tulijoita. Se ei tee tarpeettomaksi, että myös metallialan osalta määritellään työvoimapohjainen aikuiskoulutustavoite. Tavoite ja sen toteuttaminen ovat kaksi eri asiaa. Tavoitteen toteuttaminen konkretisoituu koulutuskapasiteetin luomisena. Kapasiteettia ei kannata perustaa, jos tavoitteen toteuttamiselta puuttuu muut edellytykset - tässä tapauksessa koulutettavat.

\section{Tavoitteiden merkitys}

Tavoitteen asettamisen merkitys on siinä, että se kiinnittää huomion sen toteuttamisen edellytyksiin, joihin toiminnalla myös voidaan vaikuttaa. Yksi tapa vaikuttaa koulutushalukkuuteen on tiedottaa koulutusmahdollisuuksista. Tieto vaikuttaa ihmisten päätöksiin ja toimintaan. Tiedon kautta tarjonta luo oman kysyntänsä.

Toinen tapa on ryhtyä tutkimaan asiaa: mistä syystä metallialalle ei ole tulijoita? Syyski voi paljastua alan huono palkkaus, kehnot työolot jne. Syiden selvittyä voidaan ruveta muuttamaan olosuhteita. Mutta kaiken toiminnan edellytyksenä on selkeiden, täsmällisten tavoit- teiden määritteleminen. Niin kauan kuin tavoitteet ovat epämääräisiä mielikuvia tai pelkkiä asenteita, niin kauan myös toiminta jää hajanaiseksi ja ponnettomaksi, eikä johda tuloksiin.

Mahdollisesti tutkijat pelkäävät, että metallialalle asetetut, tällä hetkellä epärealistisilta näyttävät tavoitteet syövät toisten, väestön koulutuskysynnän kannalta vetävämpien alojen mahdollisuuksia lisätä koulutustaan. Pelolle on katetta nuorisoasteen koulutuksen kohdalla. Joillekin aloille on enemmän tulijoita kuin voidaan ottaa, toisten alojen koulutuspaikat jäävät tyhjiksi. Kokonaismäärän ollessa annettu, koulutuspaikkojen siirtäminen kysytylle alalle edellyttää supistuksia vähemmän suositulta alalta. Sitä taas ei voida tehdä, kun jälkimmäisen alan koulutus on mitoitettu työvoimatarpeen pohjalta.

Tämä on ongelma, jota voidaan lieventää, mutta ei kokonaan ratkaista niin kauan kuin koulutuksen yhtenä tehtävänä on tuottaa työvoimaa. Aikuiskoulutuksen tämänhetkisessä tilanteessa ongelma on kuitenkin luonteeltaan teoreettinen. Neuvottelukunnan eri aloille asettamat tavoitteet ovat niin kaukana niiden koulutustarjonnan nykyisestä määrästä, että kestää vuosikausia ennen kuin tavoitteiden mukainen kapasiteetti on luotu. Minkään alan tavoitteet eivät estä toisten tavoitteiden toteuttamista.

Tulevaisuudessa nyt asetetut tavoitteet saavutetaan, jolloin ongelma saattaa muodostua käytännölliseksi. On kuitenkin selvää, että neuvottelukunnan mietinnössään asettamat tavoitteet ovat vasta alkusoittoa aikuiskoulutuksen todelliselle kehitykselle; aika näyttää kuinka suureksi aikuiskoulutus loppujen lopuksi muodostuu.

\section{Vaihtoehdot}

Aikuiskoulutuksen mitorttamisen menetelmiä kannattaa kuitenkin pohtia. Ei ole itsestäänselvyys, että nuorisoasteella sovelletut menetelmät istuvat aikuiskoulutukseen.

Tutkijat korostavat subjektiivisen koulutuskysynnän merkitystä ja katsovat, että työvoimamenetelmä johtaa aikuisten "'pakkokouluttamiseen" (s. 88). Neuvottelukunnan esitysten taustalla ovat kuitenkin varsin käytännölliset syyt.

Voimme tarkastella asiaa olettamalla, että nuorisoasteen koulutuksen suunnittelussa käytetään työvoima- ja aikuiskoulutuksen kysyntämenetelmää. Jos aikuisten koulutus järjestetään vastaamaan nuorisoasteen koulutustutkintoja, kuten on ajateltu, voimme joutua tilan- 
teeseen, jossa joidenkin alojen työvoiman tarjonta ylittää sen kysynnän.

Tuskin on oletettavissa, että aikuiset käyttäytyisivät 'järkevämmin' kuin nuoret; myös heille koulutus olisi väline parempien yhteiskunnallisten asemien tavoittelussa. Kysyntämenetelmän soveltamisen tuloksena olisi, että paitsi aikuiset myös nuoret joutuisivat kärsimään aikuisten valintojen seurauksista, työttömyydestä, sijoittumisesta koulutusta vastaamattomiin työpaikkoihin jne. Tämä on se käytännön syy, minkä takia myös aikuisten koulutus tulee suunnitella työvoimamenetelmällä.

Voidaan ajatella, että nyt alkuvaiheessa kun aikuiskoulutus on vähäistä, koulutuksen annettaisiin kehittyä kysynnän mukaan ja vasta myöhemmin kun ongelmia alkaa esiintyä, ryhdyttäisiin kehitystä jarruttelemaan. Se on mahdollista, mutta miksi ajautua vaikeuksiin tieten tahtoen?

Toinen mahdollisuus on, että irotetaan koulutus työelämästä joko kokonaan ja työtehtävien opetus järjestettäisiin työpaikoilla kuten Kivinen, Rinne ja Ahola ehdottavat tuoteimmassa kirjassaan "'Koulutuksen rajat ja rakenteet" (s. 153-154). Ehdotukseen kuuluu, että välttämätön teoria opetettaisiin koulussa.

Ehdotuksen huono puoli on siinä, että se on ristiriidassa tutkijoiden vaatiman perusval- miuksien opettamisen kanssa. Opettajat opettavat mitä osaavat, mutta joka tapauksessa he opettavat enemmän kuin työpaikoilla pystytään opettamaan. Useimpien työpaikkojen työt ovat vain kapea siivu ammattialan kokonaisuudesta; miten siis varmistetaan laaja-alaiset perusvalmiudet?

Turkulaisten malli ei poista ammatillisen koulutuksen suunnittelun ongelmaa, sillä malliin sisältyvä "teorian" opetus pitää ongelman hengissä. Teorian opetus edellyttää opettajia, rakennuksia ja myös koneita ja kalustoa. Kun teoria on eri ammattialoilla erilaista, jonkun täytyisi päättää kuinka paljon eri alojen opettajia koulutetaan, kuinka paljon tiloja ja välineitä niiden opetus tarvitsee. Toiminta pyörisi hyvin, jos muutoksia ei tapahtuisi. Kiusallista on se, että niitä kuitenkin tapahtuu, halusimmepa sitä tai emme. Muutokseen täytyy varautua, siis suunnitella koulutusta.

Turkulaisten malli herättää toisenkin kysymyksen. Lisääntyykö aikuisen vapaus siitä, jos valikointi koulutukseen siirtyy koulutusjärjestelmästä työpaikoille. On perusteltua olettaa, että samat sosiaalisen nousun voimat ohjaavat hakeutumista työpaikkakoulutukseen kuin oppilaitosmuotoiseen koulutukseen. Meillä olisi kohta tilanne, jossa haluttuihin työpaikkoihin ja yrityksiin olisi enemmän tulijoita kuin niihin voidaan ottaa ... Tuttu ongelma?

\section{LÄHTEET}

Osmo Kivinen, Risto Rinne, Sakari Ahola, Arto Kankaanpää. Työelämä, koulutus ja ennusteet. Opetusministeriön suunnittelusihteeristön julkaisuja 6. Valtion painatuskeskus. Helsinki 1989.

Osmo Kivinen, Risto Rinne, Sakari Ahola. Koulutuksen rajat ja rakenteet. Hanki ja jää. Helsinki 1989.

Väestön koulutus 2000. Koulutussuunnittelun neuvottelukunta. Komiteanmietintö 1988:28. Helsinki 1988. 